\title{
INTEREST ANALYSIS IN INTERJURISDICTIONAL MARRIAGE DISPUTES
}

\author{
TOBIAS BARRINGTON WOLFF ${ }^{\dagger}$
}

\section{INTRODUCTION}

Gay and lesbian couples are now entering into legally authorized marriages for the first time in our nation's history. As has happened many times before when significant policy differences have emerged among the civil marriage laws of different jurisdictions, these newly married couples will inevitably move about the country, and state courts will have to decide whether, when, and for what purpose to give effect to their marriages when forum law would have prohibited the couples from marrying locally. The debate over this recognition problem is already fully joined. Thus far, however, that debate has most frequently been characterized by positions that are sweeping and unconditional. On one side, skeptics argue that the federal Defense of Marriage Act $^{1}$ and the public policy exception in choice-of-law analysis together grant states the power to disregard any marriage that contravenes local law. On the other side, advocates of recognition invoke an array of constitutional arguments-based upon equality principles, vested right theories, and claims about the privileges of citizenshipto contend that states may never exercise such a discriminatory and disruptive power against the marriages of gay couples. These are the lightning and thunder of legal analysis: categorical claims of state authority met with categorical claims of constitutional invalidity.

It is not surprising that a contentious issue would provoke a contentious debate, and this focus on broad questions of state power and

\footnotetext{
${ }^{\dagger}$ Professor of Law, University of California, Davis Law School. I am grateful to Francesca Gessner, whose brilliant research assistance made an indispensable contribution to this project.

I presented an earlier version of this Article at "Current Debates in the Conflict of Laws," a symposium sponsored by the University of Pennsylvania Law Review, and I benefited greatly from the comments of my distinguished fellow panelists Herma Hill Kay, Andy Koppelman, and Linda Silberman. My thanks to Kim Roosevelt and to the Law Review for putting together such a successful gathering. I also thank Aaron Belkin, Alan Brownstein, and Joe Singer for their generous attention to this Article, and the members of the Law Review for their excellent editorial work.

${ }^{1} 28$ U.S.C. $§ 1738 \mathrm{C}(2000)$.
} 
constitutional principle is both necessary and appropriate-the more so in the wake of the Supreme Court's decision in Lawrence v. Texas, ${ }^{2}$ which has fundamentally altered the reception that gay couples can expect when they assert constitutional claims. Many of the disputes that state courts will confront when married gay couples move and travel around the country, however, will not be resolved by the heat and noise of this debate. Until the Supreme Court of the United States is prepared to place its institutional capital behind a principle of fully equal treatment for gay and lesbian couples-as I believe it will, in time-those couples must be prepared to engage courts in a discussion about what is sensible and advisable, not merely what is mandatory or prohibited.

Among the most important elements in that discussion, and my focus in this Article, will be an examination of the range of interests that a state may assert in considering whether to give effect to a gay couple's marriage. That examination does require some attention to recent constitutional developments. While the Court has assiduously avoided any statement about the constitutional right of gay couples to marry in its recent decisions, it has nonetheless established principles that inform the range of interests that a state may legitimately assert as a basis for denying recognition to the validly celebrated marriages of those couples.

In the body of cases produced by past disputes over racially mixed marriages, consanguineous or incestuous relationships, marriages involving minors, and other contentious relationship categories, state courts have relied upon two primary rationales for refusing to give effect to marriages that have been validly celebrated in other jurisdictions: a desire to exclude certain sexual couplings or romantic relationships entirely from their borders; and a desire to express the moral disapproval with which the state regards the disputed relationship. Some courts have also hinted at a third rationale that functions as a corollary of sorts to the first two: a desire to dissuade couples in the disfavored relationship from migrating to the state in the first place. The legitimacy of each of these state interests, as applied to gay couples, is now in serious doubt. In Lawrence, the Court held that a state may not exclude gay sexuality or gay relationships from its borders. ${ }^{3} \quad$ In Romer v. Evans, ${ }^{4}$ and also in Lawrence, the Court rejected

\footnotetext{
${ }^{2} 539$ U.S. 558 (2003).

${ }^{3} I d$. at 578-79 (holding that the Constitution's protection of personal liberty encompasses the right of consenting adults to engage in private sexual conduct without governmental interference).
} 
moral disapproval, without more, as a basis for subjecting gay citizens to selectively disfavored treatment. ${ }^{5}$ And in Saenz v. Roe, ${ }^{6}$ the Court found that a state has no legitimate interest in seeking to dissuade a class of citizens from migrating to its territory by structuring its legal entitlements to make migration more difficult. ${ }^{7}$ Together, these decisions have significantly altered the landscape for interest analysis in recognition cases.

It is not my purpose in this Article to argue that these decisions impose a constitutional duty upon states to give effect to the relationships of married gay couples. The interests described above are not the only ones that a state might attempt to rely upon in a recognition dispute. More broadly, as with Loving $v$. Virginia ${ }^{8}$ (itself an interjurisdictional marriage dispute), it seems likely that a definitive constitutional ruling on recognition will have to wait until the federal courts are ready to rule on the underlying right of gay couples to marry in the first place. Whether that decision constitutes a flash of lightning or a low rumble of fading thunder when it arrives, it can and should be preceded by a body of subconstitutional rulings by state-court judges engaged in a good-faith attempt to determine what interests are legitimately in play in a recognition case and how those interests should be analyzed. It is my hope that this Article will serve to facilitate and sharpen that inquiry.

In Part I, I canvas a broad array of interjurisdictional marriage disputes and examine in detail the interests that state courts have offered in discussing whether and for what purpose to give effect to a marriage that runs contrary to local law. I train particular focus on the three interests described above and examine the constitutional status of an attempt to apply each of these rationales to a married gay couple in the wake of Lawrence, Romer, and Saenz. In Part II, I discuss the statutes and constitutional provisions that a majority of states have now enacted to ban marriage by same-sex couples. Many of these "mini Defense of Marriage Acts," as they are often called, have used broad language to declare that marriages between gay couples are "void." Even so, the impact that these provisions should have upon the marriages of gay couples who validly marry elsewhere and then

${ }^{4} 517$ U.S. 620 (1996).

${ }^{5}$ Id. at $632,634-35$; Lawrence, 539 U.S. at 582-83.

${ }^{6} 526$ U.S. 489 (1999).

7 Id. at $492-96$.

8388 U.S. 1, 12 (1967) (holding restrictions on the freedom to marry based solely on racial classifications to be unconstitutional). 
travel or move to another state is a matter of legitimate dispute. In previous marriage controversies, courts have often required that the legislature make a clear and unmistakable statement of its intent to deny recognition to good-faith marriages performed out of state, even in the face of broad language declaring such marriages "absolutely void" when performed locally. Part II discusses the desirability of such a clear-statement rule, particularly in light of the newly constrained vocabulary of interests available to the states in seeking to deny recognition. Finally, in Part III, I place these recognition issues in a larger context by discussing the particular mode of subordination that characterizes most discrimination against gay people: the fantasy, perceptible even when it is left unspoken, that gay people and gay relationships will simply cease to exist if they are denied any type of social visibility or formal acknowledgment. The proper way to frame the analysis in a recognition dispute, I argue here, is to inquire into the most sensible way to treat the married gay and lesbian couples who will inevitably live within a jurisdiction, and not to perpetuate an unreal discussion about whether it is desirable for those couples to exist in the first place. If we expose and confront the fantasy that often obfuscates this common-sense observation, the analysis of state interests in a recognition dispute comes into even sharper focus.

\section{STATE INTERESTS IN RECOGNITION DISPUTES}

\section{A. Regulation of Intimate Conduct}

The central governmental interest that state courts have discussed in their analysis of interjurisdictional marriage disputes has been the regulation of intimate sexual conduct. In most jurisdictions, of course, marriage has been the exclusive avenue for noncriminal sexual activity for at least a portion of the state's history. In that broad sense, marriage laws have long operated in tandem with prohibitions on fornication or adultery to give an exclusive legitimacy to marital sex. More narrowly, when states have used their criminal laws to prohibit particular types of couples from engaging in any form of sexual intimacy within the jurisdiction, courts have frequently concluded that they must interpret their laws on the recognition of out-of-state marriages in harmony with that express public policy. Both in disputes where the court has granted some form of recognition to an out-ofstate marriage and in disputes where the court has refused to give such a marriage any effect, the manner in which the request for recognition would implicate the regulation of sexual conduct within the 
jurisdiction has been the primary concern. Where giving effect to a nonconforming marriage would undermine a state's restrictions on sexual conduct, courts have usually concluded that they must deny such requests. Where giving effect to a marriage would not derogate from any conduct restriction, courts have often found that the state has no strong interest in denying recognition.

This relationship between out-of-state marriages and regulation of sexual conduct has been given voice most directly in criminal prosecutions. When a couple marries in one jurisdiction, moves or returns to another jurisdiction where an intimate relationship between the two is forbidden, and then seeks to offer the marriage as a defense to a subsequent criminal prosecution, the clash between the asserted marital rights and the state's conduct restrictions is starkly presented. In most such cases, states have refused to recognize the marriage as an affirmative defense to the prosecution because doing so would directly undermine the prohibition on intimate conduct.

The decision of the Supreme Court of Tennessee in State v. Bell is one of the more frequently cited criminal cases in this respect, perhaps because it offers one of the more colorful statements of the imperative that marriage recognition doctrine must track the conduct restrictions of the local jurisdiction. Bell involved the criminal prosecution of the husband in an interracial marriage for violation of the Tennessee fornication law. The husband and his wife had been married in Mississippi, which had no antimiscegenation statute at the time, and had then come to Tennessee, where interracial relationships were categorically prohibited. The husband sought to interpose the Mississippi marriage as a defense to the prosecution, invoking the general rule that the law of the place of celebration should govern the effect given to a marriage. ${ }^{10}$ The court refused, warning that accepting that view in all cases would permit hordes of "unnatural" couplings to invade the state:

Extending [sic] the rule to the width asked for by the defendant, and we might have in Tennessee the father living with his daughter, the son with the mother, the brother with the sister, in lawful wedlock, because they had formed the relations in a State or country where they were not prohibited. The Turk or Mohammedan, with his numerous wives, may establish his harem at the doors of the capitol, and we are without rem-

\footnotetext{
${ }^{9} 66$ Tenn. 9 (1872).

${ }^{10}$ Id. at $9-10$.
} 
edy. Yet none of these are more revolting, more to be avoided, or more unnatural than the case before us.

As the Tennessee court explained some years later in expanding upon its holding in Bell, the refusal to recognize an interracial marriage as a defense to a criminal prosecution was necessary to give effect to "the very pronounced convictions of the people of this State [in the criminal code] as to the demoralization and debauchery involved in such alliances." ${ }^{212}$ Courts have routinely offered such explanations in refusing to recognize a marriage as a defense to a criminal prosecution, both in miscegenation cases ${ }^{13}$ and in prosecutions involving bigamous or consanguineous marriages. ${ }^{14}$ The former requirement in many jurisdictions that the state prove actual cohabitation before a couple could be convicted for miscegenation similarly revealed

${ }^{11} I d$. at 11 .

${ }^{12}$ Pennegar v. State, 10 S.W. 305, 307 (Tenn. 1889) (exploring distinctions between State $v$. Bell and a prosecution involving a remarriage following adultery).

${ }^{13}$ See, e.g., State v. Tutty, 41 F. 753, 761-62 (S.D. Ga. 1890) (denying effect to a D.C. interracial marriage offered as a defense to criminal prosecution for interracial fornication in Georgia); Kinney v. Commonwealth, 71 Va. (30 Gratt.) 858, 866 (1878) (refusing to recognize an out-of-state marriage as a defense in an antimiscegenation prosecution, because doing so would undermine laws of the jurisdiction that "prohibit[ed] and punish [ed] such unnatural alliances with severe penalties"); see also Loving v. Commonwealth, 147 S.E.2d 78, 82 (Va. 1966) (holding that the state's interest in refusing to recognize an interracial marriage persisted even if the state could not prosecute the couple directly for interracial sexual conduct), rev'd, Loving v. Virginia, 388 U.S. 1 (1967).

${ }^{14}$ See, e.g., United States ex rel. Devine v. Rodgers, 109 F. 886, 888 (E.D. Pa. 1901) (refusing to recognize a marriage between an uncle and his niece as a defense against deportation because "a continuance of the relation ... would at once expose the parties to indictment in the criminal courts, and to punishment by fine and imprisonment in the penitentiary"); People v. Ezeonu, 588 N.Y.S.2d 116, 118 (Sup. Ct. Bronx County 1992) (denying effect to a husband's purported second marriage in Nigeria as a defense to a statutory rape charge involving a thirteen-year-old girl in New York); State v. Brown, 23 N.E. 747, 750 (Ohio 1890) (refusing to read an exception for validly married couples into a statute criminalizing sex between an uncle and his niece because the state is "not bound, upon principles of comity, to permit persons to violate our criminal laws ... because they have assumed, in another state or country where it was lawful, the relation which led to the acts prohibited by our laws"); Pennegar, 10 S.W. at 308 (denying effect to a second marriage by a couple who married following the wife's divorce for adultery in a previous marriage, because "their return to this State and cohabiting as man and wife" violated Tennessee's "lewdness" statute and threatened "public morals, peace, and [the] good order of society"); see also Commonwealth v. Lane, 113 Mass. 458, 461-62 (1873) (preventing the prosecution of a Massachusetts man who was divorced on grounds of adultery and then traveled to New Hampshire to evade a local restriction and marry his former lover, because the relationship was not absolutely prohibited under Massachusetts law); State v. Fenn, 47 Wash. 561, 565 (1907) (arriving at a similar conclusion for a Washington citizen who traveled to British Columbia to remarry shortly following a local divorce). 
the concern with regulation of intimate conduct that lay at the core of these prosecutions. ${ }^{15}$ To be sure, there are exceptions to this rulecases in which courts have allowed criminal defendants to shield themselves from prosecution through the invocation of a nonconforming marriage. ${ }^{16}$ But the paucity of such exceptions in the criminal context proves the rule, and, even in such cases, the state's interest in reinforcing its local restrictions on intimate conduct has loomed large in the conflicts analysis. ${ }^{17}$

Outside the context of criminal prosecution, in contrast, courts have frequently given effect to marriages that would violate local restrictions on intimate conduct, provided that the purpose for which the marriage is offered does not involve the introduction of that prohibited conduct into the state. The issue arises most frequently in disputes over inheritance and probate, where one party makes claims upon an estate that depend upon the validity of the decedent's out-ofstate marriage. Obviously enough, the court can give effect to a marriage in administering an estate without licensing any prospective violations of the jurisdiction's criminal code. Many courts have explained that the state has no weighty interest in denying effect to an out-of-state marriage in such a case, precisely because the invocation of the marriage in probate does not interfere with local conduct restrictions. In the absence of any argument about the regulation of in-

${ }^{15}$ See Andrew Koppelman, Interstate Recognition of Same-Sex Civil Unions: A Handbook for Judges, 153 U. PA. L. REV. 2143, 2151 n.36 (collecting cases illustrating this phenomenon).

${ }^{16}$ See, e.g., State v. Ross, 76 N.C. 242, 246-47 (1877) (recognizing an out-of-state interracial marriage as a defense in a criminal prosecution for fornication and adultery, despite the invalidity of the marriage in the local jurisdiction); see also State v. Graves, 307 S.W.2d 545, 551 (Ark. 1957) (permitting the husband and parents of an underage bride to invoke marriage as a defense to criminal prosecution for delinquency of a minor, despite deliberate evasion of Arkansas marriage laws). But see State v. Kennedy, 76 N.C. 251, 253 (1877) (refusing, in a companion case to Ross, to recognize an out-of-state interracial marriage where the North Carolina couple clearly and deliberately evaded local marriage restrictions).

${ }^{17}$ See Ross, 76 N.C. at 246 ("However revolting to us and to all persons ... [an interracial] marriage may appear, such cannot be said to be the common sentiment of the civilized and Christian world."); $i d$. at 247 ("The only evil which could be avoided by [denying effect to the marriage] is that the people of this State might be spared the bad example of an unnatural and immoral but lawful cohabitation."); id. at 250 (Reade, J., dissenting) ("[I]ndividuals who have formed relations which are obnoxious to our laws can find their comfort in staying away from us."); see also Graves, 307 S.W.2d at 554 (Smith, J., concurring) ("It was at first my inclination to ... [say] that although the validity of this marriage would be recognized in this state our policy against underage marriages should prevent the couple from living together until attaining the age at which they might have been married in Arkansas ...."). 
timate conduct within the jurisdiction, these courts have often concluded, the state has no good reason to frustrate the private reliance interests of the parties or to depart from the general rule of comity that calls for the recognition of marriages that were valid where performed. $^{18}$

The decision of the California Court of Appeals in In re Dalip Singh Bir's Estate makes the point succinctly. ${ }^{19}$ Dalip Singh Bir involved the probate of the California holdings of a native of India who died intestate in California, leaving two wives in India who both made claims upon the estate as widows. Both women had lawfully married the decedent in India and had lived with him in the Punjab Province, but the trial court in California refused to recognize the validity of the more recently celebrated marriage in the probate proceeding, concluding that local law only permitted the court to give effect to one of

\footnotetext{
${ }^{18}$ As conflicts scholars must explain with increasing frequency, the decision by one state to give effect to a marriage performed in another state is a matter of comity, not constitutional or federal mandate. The Full Faith and Credit Clause, U.S. CONST. art. IV, $\S 1$, and its federal implementing legislation, 28 U.S.C. $\$ 1738$ (2000), impose a mandatory duty of recognition upon judgments, but legislative enactments and licenses carry no such weight. Compare Baker v. Gen. Motors Corp., 522 U.S. 222, 233-34 (1998) (holding that full faith and credit recognizes no public policy exception for the enforcement of judgments, which must be given effect when rendered by a court of competent jurisdiction), with Allstate Ins. Co. v. Hague, 449 U.S. 302, 308 (1981) (plurality opinion) (finding that a court conducting a choice-of-law analysis may disregard the law of another jurisdiction provided that local law has "significant contact or [a] significant aggregation of contacts, creating state interests, with the parties and the occurrence or transaction”), and Williams v. North Carolina, 325 U.S. 226, 227 (1945) (recognizing the power of one state to give no effect to a divorce decree entered by another state where the forum concludes that the parties were not domiciled in the state issuing the decree at the time of its issuance).

Of course, a court must act consistently with the other demands of the U.S. Constitution when it chooses whether to give effect to an out-of-state marriage. Loving itself, for example, was a recognition dispute involving a criminal prosecution in which Virginia refused to give effect to an interracial marriage performed in the District of Columbia. The basis of the Supreme Court's holding in that case was that Virginia had chosen an illegitimate basis on which to deny recognition to that marriage (and on which to prohibit the Lovings from marrying locally). Loving v. Virginia, 388 U.S. 1, 11 (1967). Professor Kramer has argued that the Full Faith and Credit Clause itself imposes an obligation upon states to choose neutral criteria for determining when to give effect to domestic laws, rather than making judgments based upon mere policy preferences. See Larry Kramer, Same-Sex Marriage, Conflict of Laws, and the Unconstitutional Public Policy Exception, 106 YALE L.J. 1965, 1967-68 (1997). That view has not yet gained wide acceptance.

${ }^{19} 188$ P.2d 499 (Cal. Dist. Ct. App. 3d Dist. 1948). Dalip Singh Bir is a regular staple of the conflicts casebook. See, e.g., David P. Currie, Herma Hill Kay \& Larry KRAMER, CONFLICT OF LAWS: CASES, COMMENTS, QUESTIONS 37 (6th ed. 2001).
} 
the marriages. ${ }^{20}$ The appeals court reversed, concluding that there was no good reason to deny effect to the marriage when doing so would not interfere with any restrictions on the regulation of intimate conduct within California:

The decision of the trial court was influenced by the rule of "public policy" [against polygamous marriages]; but that rule, it would seem, would apply only if decedent had attempted to cohabit with his two wives in California. Where only the question of descent of property is involved, "public policy" is not affected. ${ }^{21}$

${ }^{20}$ Dalip Singh Bir, 188 P.2d at 499-500.

${ }^{21} I d$. at 502. The Supreme Court of Louisiana appears to have reached a similar conclusion in a miscegenation case, though it was less explicit in its reasoning. In Succession of Caballero (Mrs. Conte) v. Executor, 24 La. Ann. 573 (1872), that court took cognizance of a Spanish marriage between a "colored woman" and a white man for purposes of probating the husband's estate. In holding that Louisiana law did not prevent that result, despite its prohibition on interracial marriage, the court explained that Louisiana law:

$[\mathrm{C}]$ ould not and did not aim to affect elsewhere the validity of a marriage like

that of the parents of the plaintiff. It was strictly personal to parties living in

Louisiana, who had anywhere contracted the kind of marriage not permitted by its policy, and did not, as in the plaintiff's case, affect the children of such parents legitimated in other countries and not incapacitated here on other grounds. The policy of this State had no broader extent, because there was no reason why it should have.

$I d$. at 575. Louisiana's antimiscegenation statute was concerned only with the regulation of the behavior of Louisiana domiciliaries within the state (being "strictly personal to parties living in Louisiana") and, foreshadowing Dalip Singh Bir, there was "no reason" to apply the prohibition where that interest was not implicated.

The Supreme Court of Florida also permitted its courts to take cognizance of an out-of-state interracial marriage where the couple "did [not] reside" within the state subsequent to their marriage. Whittington v. McCaskill, 65 Fla. 162, 164 (1913). The court issued that ruling despite statutes criminalizing interracial marriage and declaring such relationships "utterly null and void." Id.

In 1990, the Court of Appeals of New Mexico issued a fascinating decision that also embraces a similar mode of reasoning. The case, Leszinske v. Poole, 798 P.2d 1049 (N.M. Ct. App. 1990), involved a custody dispute between a divorced couple over their three children. The mother had become intimately involved with her maternal uncle following the divorce, a relationship (and marriage) that was illegal under New Mexico law, and the father offered that relationship as a basis for denying her custody. In response, the trial court actually encouraged the mother to follow through on a plan to evade the marriage laws of New Mexico by traveling to Costa Rica to marry the uncle and then relocating to California, where the liberal recognition laws would treat the marriage as valid. The court permitted the mother to retain custody on the condition that she and the uncle enter into such a valid (if evasive) marriage. Id. at 1051. In reviewing the propriety of that order, the Court of Appeals stressed that it did not need to "decide whether New Mexico would recognize the marriage mother planned in all circumstances and for all purposes" but rather needed only to "decide whether, for purposes of awarding mother primary physical custody, the district court did not err in taking the planned marriage into account." Id. at 1053. Despite New Mexico laws 
The California court joined a host of others in reaching this conclusion. In Mississippi, the supreme court held in 1948 that interracial marriages should be given effect in probate proceedings, despite that state's antimiscegenation laws, because the "manifest and recognized purpose of" those laws "was to prevent persons of Negro and white blood from living together in this state" and, where there is no request for in-state cohabitation, "to permit one of the parties to such a marriage to inherit property ... does no violence" to the policy. ${ }^{22}$ In New York, in another widely discussed case, the Court of Appeals gave effect to the Rhode Island marriage of a Jewish uncle and niece in probate proceedings, although the marriage was prohibited in New York, because it found nothing in the positive law of New York that declared such out-of-state marriages so "void" as to require exclusion of the relationships from the jurisdiction for all purposes. ${ }^{23}$ The Maryland Court of Appeals came to a similar conclusion when it confronted another such Rhode Island marriage. ${ }^{24}$

As with the criminal prosecutions, there are some exceptional probate cases that come out the other way. But even most of the outlier cases maintain a consistent focus on the centrality of conduct regulation in describing the state interests that drive the decision. In some instances where courts have refused to give any effect to an outof-state marriage in probate, even where doing so would not derogate from local conduct restrictions in any direct way, the court has identi-

criminalizing sexual relations between an uncle and niece and declaring marriages between the two "absolutely void," $i d$., the court found that the public policy of the state did not require reversal because "awarding mother primary physical custody . . . was in the best interests of the children and mother and uncle intended to reside in California," Id. at 1056.

${ }^{22}$ Miller v. Lucks, 36 So. 2d 140, 142 (Miss. 1948). In 1875, the Supreme Court of California went so far as to give effect, for probate purposes, to the marriage of a master and his slave celebrated in the territory of Utah before Emancipation, despite California's prohibition on interracial marriage. Pearson v. Pearson, 51 Cal. 120, 124-25 (1875). The court's conclusion in that case that the marriage was valid, despite the status of the woman as a slave (and hence unmarriageable) at the time of celebration, carries forward the conclusion that jurists came to gradually in the nineteenth century that slavery could be sustained, if at all, only through the continuing operation of positive law. See Tobias Barrington Wolff, The Thirteenth Amendment and Slavery in the Global Economy, 102 Colum. L. REV. 973, 997-1005 (2002) (discussing positive-law treatment of slavery in interjurisdictional disputes).

${ }^{23}$ In re May's Estate, 114 N.E.2d 4, 7 (N.Y. 1953).

${ }^{24}$ Fensterwald v. Burk, 98 A. 358, 360 (Md. 1916). Both courts concluded that marriages between uncles and nieces, though in violation of local law and "voidable" during the life of the parties, were not so contrary to public policy as to be "void" and, by implication, necessarily excluded from the jurisdiction in their entirety. Id. at 13739; In re May's Estate, 114 N.E.2d at 6-7. 
fied the criminal prohibition on intimate conduct as the source of the weighty policy statement that has required that result. ${ }^{25}$ In other cases, the court has identified another extraneous consideration that militates against recognition on general conflicts principles despite the absence of any threat to local restrictions on conduct, for example, a deliberate attempt by in-state residents to evade the local marriage laws. ${ }^{26}$

In states where the legislature has chosen not to criminalize the intimate conduct of particular types of couples at all, though forbidding the couple from marrying within the jurisdiction, some courts have taken the absence of a conduct regulation to indicate that the state has little or no interest in denying effect to a valid marriage from another state. The Supreme Court of Kansas issued a holding to that effect in 1981, for example, in a probate case involving a marriage between first cousins. "Although our statutes prohibit first cousin marriages and impose criminal penalties where such marriages are contracted in Kansas," the court explained:

[W] e cannot find that a first cousin marriage validly contracted elsewhere is odious to the public policy of this state. The reason for the inclusion of first cousins in [the Kansas marriage prohibition] has become less compelling in recent years as evidenced by the legislature's omission of sexual intercourse between first cousins in the definition of incest. ${ }^{27}$

The Supreme Court of Ohio is the only court of which I am aware that has expressly come to a different conclusion, and it did so by rejecting one of its own precedents that had previously embraced the argument. $^{28}$

${ }^{25}$ See, e.g., Catalano v. Catalano, 170 A.2d 726, 728 (Conn. 1961) (refusing to give effect to a marriage between an uncle and his niece in a probate action because such incest carries a penalty of ten years imprisonment and " $[\mathrm{t}]$ his relatively high penalty clearly reflects the strong public policy of this state"); Rhodes v. McAfee, 457 S.W.2d 522,524 (Tenn. 1970) (refusing to give effect to the "incestuous" marriage of a stepfather and his stepdaughter in an action for dower, because "where the same facts which statutorily prohibit the marriage are also made a penal violation, such is indicative of the pronounced conviction of the people of this State regarding such marriages").

${ }^{26}$ See, e.g., In re Mortenson's Estate, 316 P.2d 1106, 1106-08 (Ariz. 1957) (refusing to give effect to an interracial marriage during probate where the Arizona spouses had deliberately evaded a local prohibition); Eggers v. Olson, 231 P. 483, 483-86 (Okla. 1924) (same); Greenhow v. James' Executor, 80 Va. 636, 638-41 (1885) (same); see also Brinson v. Brinson, 96 So. 2d 653, 659-60 (La. 1957) (refusing to give effect to a "bigamous" marriage that preceded the husband's divorce from his first wife where the spouses went to a neighboring state and contracted marriage "in bad faith," presumably to evade the local prohibition on bigamy).

${ }^{27}$ In re Estate of Loughmiller, 629 P.2d 156, 161 (Kan. 1981).

${ }^{28}$ That court refused to give effect to an out-of-state marriage between an uncle 
In short, throughout these varied forms and configurations of interjurisdictional marriage dispute, the reinforcement of a jurisdiction's laws prohibiting disfavored intimate conduct has been the dominant pragmatic interest that courts have identified in applying their own restrictive laws to out-of-state marriages that were valid where performed. "Dominant" does not mean "exclusive." As I will discuss in the sections that follow, courts have recognized other interests that states may assert in denying effect to nonconforming marriages. But the desire to prohibit disfavored sexual conduct and to exclude disfavored relationships from the jurisdiction has been the primary pragmatic concern around which state marriage-recognition doctrines have taken shape. Thus, in a modern dispute concerning the out-of-state marriage of a gay or lesbian couple, one of the first questions that most state courts might be expected to ask is how a request for recognition implicates the state's policies concerning the regulation of sexual intimacy and cohabitation by same-sex couples.

The range of legitimate answers to that question has changed dramatically in the wake of Lawrence $v$. Texas. The Supreme Court in Lawrence interpreted the substantive right to "liberty" in the Due Process Clause to extend its protection to intimate sexual conduct between two partners of the same sex, declaring unconstitutional all those laws that had prohibited private "sodomy" (oral or anal sex) between consenting adults in a noncommercial setting. ${ }^{29}$ The Court situated this holding within a larger discussion of the relationships of gay and lesbian couples, using unprecedented language to insist upon the equal dignity of those relationships under the Constitution and explaining

and a niece, despite the repeal by the Ohio legislature of the criminal prohibition on sexual intercourse for such couples, writing:

One of the purposes of the new Criminal Code was to decriminalize certain unlawful sexual behavior and leave the parties to whatever chastisement society would impose without making them criminally liable. It was supposedly an enlightened approach to "social crimes." We do not believe that the General Assembly intended to change the state's public policy so as to favor fornication, adultery, rape of one spouse by the other, sodomy, fellatio, homosexuality and some forms of incest.

In re Estate of Stiles, 391 N.E.2d 1026, 1027 (Ohio 1979) (citation omitted). In an earlier case, the same court had suggested that the absence of a criminal prohibition on intimate conduct indicated that a disfavored marriage was not so "void" as to require denial of recognition when the marriage was validly performed out of state. See Mazzolini v. Mazzolini, 155 N.E.2d 206, 208 (Ohio 1958) ("It will thus be seen that firstcousin marriages in this state are not made void by explicit provision to that effect. Moreover ... sexual relations between cousins are not incestuous."). The Stiles Court treated this precedent derisively and limited it to its facts.

${ }^{29}$ Lawrence v. Texas, 539 U.S. 558, 578-79 (2003). 
that the protection of sexual intimacy for gay couples forms part of a larger protection of their ability to enter into and maintain lasting intimate relationships. ${ }^{30}$ Although the Lawrence case itself did not deal with an attempt by the state to prevent a gay couple from cohabiting, the liberty interest that the opinion extends to gay couples clearly includes the right to maintain a family home, a right that straight couples have enjoyed for some time. ${ }^{31}$ Following Laurence, same-sex couples have a right to enjoy private intimacy and to share a household in which they can hold themselves out to their community as participants in a committed relationship.

Despite the dramatic change that it effectuates in the relationship rights of gay men and lesbians, Lawrence does not, of its own force, confer a right upon same-sex couples to marry. The Court took care to exclude the question of marriage from the ambit of its holding. ${ }^{32}$ In future disputes involving the constitutionality of laws prohibiting gay couples from marrying, courts will have to determine whether Lawrence's holding on liberty rights, issued in the context of a criminal prosecution, should be extended to the denial of civil benefits and obligations-a real but very different type of burden to impose upon a relationship.

\footnotetext{
${ }^{30}$ For example, in describing the nature of the liberty interest that it was recognizing, the Court wrote:

It suffices for us to acknowledge that adults may choose to enter upon this relationship in the confines of their homes and their own private lives and still retain their dignity as free persons. When sexuality finds overt expression in intimate conduct with another person, the conduct can be but one element in a personal bond that is more enduring. The liberty protected by the Constitution allows homosexual persons the right to make this choice. Id. at 567 .

Professor Katherine Franke has raised questions about the Lawrence Court's decision to couch this liberty interest in such "domesticated" terms. By identifying the worth of sexual behavior exclusively in terms of a "more enduring" relationship, Franke argues, the Court has offered a somewhat constrained form of sexual freedom and, as it happens, mischaracterized the facts of the Lawrence case itself, in which the defendants were not involved in a committed relationship. See Katherine M. Franke, The Domesticated Liberty of Lawrence v. Texas, 104 CoLuM. L. REV. 1399, 1407-08 (2004).

${ }^{31}$ See, e.g., Moore v. City of East Cleveland, 431 U.S. 494, 505-06 (1977) (recognizing the constitutional right of a family to maintain a home together and extending that right beyond the nuclear family to include a grandmother and her grandsons); Griswold v. Connecticut, 381 U.S. 479, 485 (1965) (identifying the protection of the "marital bedroom" from intrusion by a state as one rationale for invalidating a restriction on the use of contraceptives by a straight married couple).

${ }^{32}$ Lawrence, 539 U.S. at 578 ("The present case ... does not involve whether the government must give formal recognition to any relationship that homosexual persons seek to enter.”).

${ }^{33}$ See id. at 575 (discussing the particular stigma of criminality that Texas law im-
} 
Nonetheless, the Lawrence opinion does have an immediate impact upon the range of interests that a state may legitimately assert when presented with a request to give effect to a valid marriage from another jurisdiction. Heretofore, the recognition doctrines in many jurisdictions have taken shape around a policy of excluding disfavored conduct from the borders of the forum state. The primary interest that states have asserted in such disputes, consistent with their laws prohibiting sex and cohabitation, has been an interest in maintaining a community in which certain forms of sexual and intimate relationship are not present. Following Lawrence, a state can no longer claim any legitimate interest in excluding the relationships of gay and lesbian couples from its borders.

\section{B. Expressions of Moral Disapproval}

The other principal state interest that courts have invoked in denying effect to out-of-state marriages has been a jurisdiction's desire to express moral disapproval toward certain types of intimate relationship. This symbolic or expressive interest is frequently offered in tandem with the state's more pragmatic desire to exclude the relationship from the jurisdiction altogether. Since there has been no serious disagreement over the state's power to regulate the sexual conduct of its inhabitants in most of the interjurisdictional marriage disputes on record, courts have not precisely delineated the independent work that each of these state interests has performed in justifying a refusal to give effect to a disfavored marriage. ${ }^{34}$ Rather, the jurisdiction's ex-

posed upon gay couples); id. at 581-82 (O’Connor, J., concurring) (same).

${ }^{34}$ The most noteworthy exception here is the decision of the Virginia Supreme Court in Loving v. Commonwealth, 147 S.E.2d 78 (Va. 1966), rev'd, Loving v. Virginia, 388 U.S. 1 (1967), issued two years after the Supreme Court of the United States had proclaimed in McLaughlin v. Florida, 379 U.S. 184 (1964), that states could not single out interracial fornication for particular criminal penalty. In preserving Virginia's ban on marriage between interracial couples despite the state's inability to prohibit their sexual intimacy, the court reverted to a statement about morality, as given voice by the Supreme Court of the United States in Maynard v. Hill, 125 U.S. 190, 205 (1888): "Marriage, as creating the most important relation in life, as having more to do with the morals and civilization of a people than any other institution, has always been subject to the control of the legislature." It bears noting that this passage, often reproduced by courts when ruling that a couple does not have a constitutionally enforceable right to marry, is almost always quoted out of context and given a false meaning, as was the case in the Virginia Supreme Court's opinion in Loving. The Maynard case involved a challenge to a declaration of divorce issued by the legislature of the Washington Territory, which the disappointed party claimed was beyond the power of the legislature because a divorce decree is inherently judicial in nature. The Supreme Court rejected that argument and upheld the decree, and the quoted language appears in 
pression of moral disapproval has served as a symbolic counterpoint to its use of the criminal code to exclude the relationship from the state. ${ }^{35}$

Expressions of moral disapproval appear most frequently in discussions of incest and consanguinity. Joel Prentiss Bishop, the nineteenth-century treatise author whom courts relied upon widely in early marriage disputes, offered the following account of the general rule:

\begin{abstract}
Should there be, as occasionally may happen, a country or State permitting marriages which by the common voice of civilized nations are vicious past toleration, such marriages, though solemnized under the protection of its laws, would not be within the protection of the law of nations because lacking the general favor essential.... [Such a marriage] must be contrary also to the common voice of Christendom. The familiar illustrations, perhaps the only ones of which a writer can speak with absolute assurance, are polygamous marriages and those of excessively near consanguinity.
\end{abstract}

In particular, when courts draw distinctions between marriages that are "void," "absolutely void," or "void ab initio" and those that are merely "prohibited"-as with consanguineous marriages within a primary blood line (siblings; parents and children) versus those in a secondary bloodline (first cousins; an uncle and a niece)-they frequently rely upon arguments from morality to account for the state's interest in extirpating the "void" marriages from the state's borders, often invoking the language of natural law and the values of Christendom. ${ }^{37}$ In a more modern formulation, the Supreme Court of Arkan-

the Court's discussion of the legislature's competence to act on the matter. Maynard had nothing to do with the power of courts to review the constitutionality of legislative marriage policies, and the Court did not speak to the issue.

${ }^{35}$ For one example among many, see the discussion of incestuous marriages in Beggs v. State, 55 Ala. 108, 112 (1876): "Incestuous marriages are prohibited-are void $a b$ initio.... Not only are they prohibited, but those entering into them incur severe penalties... The incestuous marriage contravenes the voice of nature, degrades the family, offends decency and morals, and is absolutely interdicted." Beggs itself was about a bigamous marriage, but the court's statement on incestuous marriage has exerted influence in subsequent Alabama cases. See, e.g., Osoinach v. Watkins, 180 So. 577, 580 (Ala. 1938) (referring to Beggs as a warning to those who might, in the future, be inclined to disregard the law or undertake to evade its prohibitions).

${ }^{36} 1$ Joel Prentiss Bishop, New COMMENTARIES ON MARRiage, DivorCE AND SEPARATION $\$ \S 857-58$ (Cambridge Univ. Press 1891) (citation omitted).

${ }^{37}$ For example, in Garcia v. Garcia, 127 N.W. 586, 589 (S.D. 1910), the court stated:

Incestuous marriages as spoken of by Bishop and referred to by the authorities as being an exception to the [lex locis] rule embrace only such marriages as are incestuous according to the generally accepted opinion of Christendom, which relates only to persons in direct line of consanguinity, and 
sas, quoting Leflar, has framed the inquiry in terms of the level of "social alarm" that a disfavored marriage would engender. ${ }^{38}$ Similar assertions appear in miscegenation cases, though with considerably less frequency, ${ }^{39}$ and also in the special class of bigamy cases that arose in those states that prohibited a person who had been divorced by reason of adultery from marrying his or her paramour during the lifetime of the jilted spouse. ${ }^{40}$

brother and sisters, and does not embrace cousins.

(citation omitted); see also In re May's Estate, 114 N.E.2d 4, 7 (N.Y. 1953) (concluding that a marriage between an uncle and his niece "was not in the direct ascending or descending line of consanguinity" and so "was not offensive to the public sense of morality to a degree regarded generally with abhorrence and thus was not within the inhibitions of natural law"); Campione v. Campione, 107 N.Y.S.2d 170, 171 (Sup. Ct. Queens County 1951) (marriage between an uncle and his niece "is not universally condemned" and so recognition "is not precluded by reason of moral turpitude"). Some jurisdictions have refused to recognize even marriages within the secondary bloodline. Those courts typically invoke the same language of outraged moral sensibilities to explain that result. See, e.g., In re Estate of Stiles, 391 N.E.2d 1026, 1027 (Ohio 1979) (marriage between an uncle and his niece is "shocking to good morals" and "unalterably opposed to a well defined public policy") (citation omitted).

There appear to be very few reported cases involving marriages within the primary bloodline, presumably because no U.S. jurisdiction has ever permitted such marriages. The states have adopted divergent policies on marriage within a primary family line not related by blood, as between a stepfather and daughter, and disapproving jurisdictions have treated these unions as the equivalent of primary bloodline incest and thus void. See, e.g., Rhodes v. McAfee, 457 S.W.2d 522, 524 (Tenn. 1970) (emphasizing the importance of preventing "discord and disharmony in the family" in refusing to give effect to a stepfather/stepdaughter marriage during probate).

${ }^{38}$ See Etheridge v. Shaddock, 706 S.W.2d 395, 396 (Ark. 1986) (quoting RoBERT LEFLAR, AMERICAN CONFLICTS LAW $§ 221$ (3d ed. 1977)).

${ }^{39}$ The high court of Oklahoma provides one particularly forceful statement, borrowed from a treatise, in a case involving an evasive interracial marriage and a dispute over the title to property:

Statutes forbidding intermarriage by the white and black races were without doubt dictated by wise statesmanship, and have a broad and solid foundation in enlightened policy, sustained by sound reason and common sense. The amalgamation of the races is not only unnatural, but is always productive of deplorable results. The purity of the public morals, the moral and physical development of both races, and the highest advancement of civilization, under which the two races must work out and accomplish their destiny, all require that they should be kept distinctly separate, and that connections and alliances so unnatural should be prohibited by positive law and subject to no evasion.

Eggers v. Olson, 231 P. 483, 484 (Okla. 1924) (citation omitted); see also State v. Bell, 66 Tenn. 9, 10-11 (1872) (describing a ban on interracial marriage as protective of "good morals").

${ }^{40}$ In one such case, the Supreme Court of Tennessee wrote:

[The prohibition] is expressive of a decided State policy not to permit the sensibilities of the innocent and injured husband or wife, who has been driven by the adultery of his or her consort to the necessity of obtaining a divorce, to 
Similar discussions of morality have been ubiquitous in public debates over homosexuality and marriage. Given the prominent place that expressions of moral disapproval have occupied in past interjurisdictional marriage disputes, one can readily expect that states seeking to justify a refusal to give effect to the valid marriage of a gay or lesbian couple will take the position that such a refusal constitutes an expression of the jurisdiction's moral disapproval of gay people and their relationships. But the Supreme Court's recent decisions concerning the selective regulation of gay people have placed significant limitations on the independent doctrinal work that such expressions of moral disapproval can perform.

In the 1996 decision of Romer $v$. Evans, in its first affirmative statement on the rights of gay men and lesbians, the Supreme Court rejected the proposition that bare expressions of animus or disapproval toward homosexuality, without more, could serve as a legitimate basis for subjecting gay people to selectively disfavored treatment. ${ }^{41}$ The case involved a state constitutional amendment that had prohibited gay, lesbian, or bisexual people from claiming unequal treatment under any state law on the basis of their sexual identity. The Court found that the desire to express moral disapproval for homosexuality by making gay people "unequal to everyone else" did not constitute a "proper legislative end" that could support such a classification. Seven years later, the Court extended that holding to the state's treatment of gay couples in Lawrence $v$. Texas, overruling its own

be wounded, nor the public decency to be affronted by being forced to witness the continued cohabitation of the adulterous pair, even under the guise of a subsequent marriage, performed in another State for the purpose of evading our statute, and believing that the moral sense of the community is shocked and outraged by such an exhibition, we will not allow such parties to shield themselves behind a general rule of the law of marriage, the wisdom and perpetuity of which depends as much upon the judicious exceptions thereto as upon the inherent right of the rule itself.

Pennegar v. State, 10 S.W. 305, 308 (Tenn. 1888); see also In re Estate of Stull, 183 Pa. 625,630 (1898) (holding that a bigamous marriage following an unlawful divorce is "contrary to good morals" and not entitled to recognition). For a case coming out the other way on the issue, see Van Voorhis $v$. Brintnall, 86 N.Y. 18, 37 (1881), which held that a prohibition on remarriage following adultery is a "personal disqualification[] arising, not from the laws of nature, but from positive laws" and so does not prevent recognition of marriage performed validly in another jurisdiction.

${ }^{41} 517$ U.S. 620, 632 (1996) (ruling that an expression of "animus" toward gay people is not a legitimate basis for state regulation); $i d$. at 634-35 (stating that a "bare ... desire to harm" or disadvantage gay people does not constitute a legitimate state interest) (citation omitted).

${ }^{42} I d$. at 636 . 
earlier conclusion in Bowers $v$. Hardwick ${ }^{43}$ that moral disapproval of homosexuality could offer a sufficient basis for singling out gay couples for unfavorable legislation. ${ }^{44}$ Lawrence itself rested on the protection of liberty in the Due Process Clause. In a separate concurrence, however, Justice O'Connor gave the equal protection argument more prominence, explicitly resting her vote for reversal upon the proposition that "moral disapproval, without any other asserted state interest, is [not] a sufficient rationale under the Equal Protection Clause to justify a law that discriminates among groups of persons ${ }^{\text {"45 }}$-a proposition that the majority acknowledged as "tenable."

There is considerable debate among constitutional scholars over the broader implications of Romer and Lawrence. The decisions certainly do not prohibit legislators from enacting policies that are consonant with broadly held moral judgments, any more than the Establishment Clause forbids a legislator from enacting a law, like a prohibition on murder, merely because it is consonant with broadly held religious beliefs. Of necessity, the decisions do rest upon the conclusion that there are well-formed and poorly formed propositions in morality for purposes of constitutional analysis. "People should not inflict physical harm upon others" is clearly a well-formed proposition in morality in this regard, while "women should not work outside the home" clearly is not. But neither opinion offers much general guidance about how to make such judgments. What Lawrence and Romer do make clear, however, is that a state must offer a concrete or tangible reason for denying equal treatment to gay people and gay couples in order to assert the "legitimate" state interest that is the minimum threshold of the Equal Protection Clause. ${ }^{47}$ An expression of moral

4348 U.S. 186 (1986).

${ }^{44}$ Lawrence, 539 U.S. at 571.

${ }^{45} I d$. at 582 (O'Connor, J., concurring in the judgment).

${ }^{46} I d$. at 574-75 (majority opinion) (invoking Romer and acknowledging applicability of that decision to state regulation that selectively disfavors gay couples).

${ }^{47}$ Justice O'Connor expands upon this requirement in her Lawrence concurrence: Moral disapproval of a group cannot be a legitimate governmental interest under the Equal Protection Clause because legal classifications must not be "drawn for the purpose of disadvantaging the group burdened by the law." Texas' invocation of moral disapproval as a legitimate state interest proves nothing more than Texas' desire to criminalize homosexual sodomy. But the Equal Protection Clause prevents a State from creating "a classification of persons undertaken for its own sake." And because Texas so rarely enforces its sodomy law as applied to private, consensual acts, the law serves more as a statement of dislike and disapproval against homosexuals than as a tool to stop criminal behavior. The Texas sodomy law "raise $[\mathrm{s}]$ the inevitable inference that the disadvantage imposed is born of animosity toward the class of 
disapproval, unsupported by any more substantial explanation of the state's interest, is no longer a proper basis for denying recognition to the validly celebrated marriage of a gay couple.

Neither can religious objections to homosexuality serve as an independent basis for such a policy. The Court has long since held that the Establishment Clause requires the state to articulate a clear secular purpose for the policies that it pursues. ${ }^{48}$ The point is an important one to make explicit in the present context for several reasons. Religious ideology often constitutes the unacknowledged agenda underlying those objections to homosexuality that are framed in terms of morality-unacknowledged precisely because of the well-established requirement that state policies be justified by secular purposes. At the same time, religious ideology is often not coextensive with the species of "animus" that Romer and Lawrence discuss at length. Particularly in the case of Christian ideology, objections to homosexuality often carry with them a message that adherents believe to be redemptive and transformative. Pursuing a loving gay relationship is sinful, under this view, but $\sin$ is a ubiquitous human condition, and some religious adherents believe that gay people should be met with an invitation to eschew their homosexuality and "sin no more," rather than with a message of pure condemnation or animus. The ultimate effect is the same-the rejection of gay people's relationships and identities-but the sentiment is different.

State courts will need to be attentive to these interlocking arguments in marriage disputes, especially when the religious sentiment underlying the rejection of a gay relationship is allowed to go unstated. The Establishment Clause forbids the state to embrace a religiously motivated policy of "redemption" as a basis for discriminating against gay couples. Romer and Lawrence forbid the state to repudiate the equal capacity for dignity in gay relationships by dressing a similar policy in lay clothing. ${ }^{49}$ The state's justification for any denial of equal treatment to gay couples must be both secular and concrete.

persons affected."

Lawrence, 539 U.S. at 583 (O'Connor, J., concurring in the judgment) (citations omitted).

${ }^{48}$ See Lemon v. Kurtzman, 403 U.S. 602, 612 (1971) (stating that a "statute must have a secular legislative purpose" to satisfy the Establishment Clause); Agostini v. Felton, 521 U.S. 203, 222-23 (1997) (reaffirming that "we continue to ask whether the government acted with the purpose of advancing ... religion" in analyzing laws under the Clause).

${ }^{49}$ See Lawrence, 539 U.S. at 567 (holding that the state may not adopt policies that deny the equal dignity of gay and lesbian relationships). 


\section{Dissuading Couples from Migrating to the State}

A third interest that courts have sometimes suggested as a reason for denying effect to an out-of-state marriage has been a state's desire to dissuade couples in a disfavored relationship from moving to the state in the first place. Unlike the interests in conduct regulation and moralistic expression, which account for a large proportion of the discussion offered by state courts in interjurisdictional marriage disputes, the desire to dissuade couples from migrating to the state is often left unstated and implicit. This is not surprising, as the desire to dissuade a couple from moving to the state is effectively subsumed within the criminal conduct regulations that prevent them from living as a couple once they arrive. Nonetheless, there are some notable exceptions. In one early antimiscegenation case, for example, the Supreme Court of Virginia made clear its view that the denial of any effect to an outof-state marriage could play a useful role in dissuading undesirable couples from migrating to the state. Affirming the criminal prosecution of the husband in an interracial couple who had been married in Washington, D.C., the court heavy-handedly opined that, "[i]f the parties desire to maintain the relations of man and wife, they must change their domicile and go to some state or country where the laws recognize the validity of such marriages., ${ }^{, 50}$ And in State v. Ross, in which the North Carolina Supreme Court recognized the valid marriage of an interracial couple as a defense to a criminal prosecution despite the existence of a local antimiscegenation policy, the dissenting judge left no doubt about the function that he believed that local law should serve in dissuading undesirable couples from coming to his state:

[I] ndividuals who have formed relations which are obnoxious to our laws can find their comfort in staying away from us.

... It is courteous for neighbors to visit and it is handsome to allow the visitor family privileges and even to give him the favorite seat; but if he bring his pet rattlesnake or his pet bear or spitz dog famous for hy-

\footnotetext{
${ }^{50}$ Kinney v. Commonwealth, 71 Va. (30 Gratt.) 858, 870 (1878). Kinney went on to request federal habeas assistance after the Virginia Supreme Court affirmed his conviction. The federal court refused to set him free. In apparent response to the state supreme court's suggestion that it could use its antimiscegenation law to deter undesirables from traveling to the state, however, the district court did explain that a man domiciled elsewhere and joined in a bona fide marriage "would have a right of transit with his wife through Virginia, and of temporary stoppage . . . because those are privileges following a citizen of the United States." Ex parte Kinney, 14 F. Cas. 602, 606 (C.C.E.D. Va. 1879) (No. 7825).
} 
drophobia, he must leave them outside the door. And if he bring small pox the door may be shut against him. ${ }^{51}$

Since it is now clear that states cannot prevent gay and lesbian couples from forming households and sharing sexual intimacy, the desire of some states to dissuade those couples from migrating may emerge as an independent and significant justification for refusing to give effect to a valid out-of-state marriage. That desire certainly finds expression in popular discussions of the marriage issue, where it is not unusual to hear those who are hostile to marriage between gay couples arguing that, if states give effect to such marriages, gay couples will be more likely to relocate or travel to the state and become a visible presence. This desire to dissuade married gay couples from joining the community echoes what William Eskridge has referred to as "no promo homo" arguments, which are pervasive in cases involving gay litigants. ${ }^{52}$ In a broad array of disputes, states sometimes structure their laws and policies to forbid government institutions from promoting or encouraging any sympathetic treatment of gay people or gay issues, particularly in employment and educational settings. ${ }^{53}$ And it is not uncommon for these antipromotion policies to turn the corner and become policies of active discouragement, seeking to dissuade gay people from participating openly in state institutions even when they cannot be excluded outright. ${ }^{54}$ It is not hard to imagine that states will offer somewhat sanitized variations on these arguments in interjurisdictional marriage disputes involving gay couples. "We cannot forbid these couples from moving to our state," the argument might go, "but

${ }^{51}$ State v. Ross, 76 N.C. 242, 250 (1877) (Reade, J., dissenting). The Kinney and Ross decisions were both issued by courts in the South at the end of Reconstruction, so it is not hard to fathom why the vocabulary of excluding undesirables from the state's borders was present in the minds of some jurists.

${ }^{52}$ See generally William N. Eskridge, Jr., No Promo Homo: The Sedimentation of Antigay Discourse and the Channeling Effect of Judicial Review, 75 N.Y.U. L. REV. 1327 (2000) (detailing the evolution of antigay rhetoric and discourse toward the position that equal treatment constitutes inappropriate "promotion" of homosexuality).

${ }^{53}$ The State of Minnesota, for example, has enacted an unusually blunt provision in this regard, adopting a "rule of construction" that provides:

Nothing in this chapter shall be construed to:

(1) mean the state of Minnesota condones homosexuality or bisexuality or any equivalent lifestyle;

(2) authorize or permit the promotion of homosexuality or bisexuality in education institutions or require the teaching in education institutions of homosexuality or bisexuality as an acceptable lifestyle .... MinN. STAT. § 363A.27 (2004).

${ }^{54}$ See Eskridge, supra note 52, at 1356-62 (discussing government programs structured to exclude or disadvantage gay people). 
we certainly don't have to make it easy for them. We are entitled to encourage these couples to move elsewhere by denying them benefits that would otherwise serve as an inducement for them to migrate to our communities."

In a recent decision involving the award of benefits to low-income families, the Supreme Court has found any such desire to dissuade unwanted citizens from migrating to one's state to be categorically illegitimate under the National Citizenship Clause of the Fourteenth Amendment. ${ }^{55}$ The Clause had been largely moribund since its early internment in the Slaughter-House Cases. ${ }^{56}$ In Saenz v. Roe, ${ }^{57}$ however, the Court invoked the principles of national citizenship in striking down a California law regarding the award of aid to families with dependent children. ${ }^{58}$ California had expressed concern that it might become a "welfare magnet" for citizens from poor states who would be attracted to the higher level of benefits that California offered. To avoid this result, the state structured its welfare regime so that newly arrived residents would be subject to a one-year probationary period during which they would only be entitled to the level of benefits that they would have received in their previous state of residence. ${ }^{59}$ In striking down this provision, the Court explained that the National Citizenship Clause embodied a right on the part of citizens to relocate freely within the United States without being subject to penalty or dissuasion. ${ }^{60}$ The Court acknowledged that states might sometimes have a legitimate interest in treating migratory arrivals differently. It preserved its earlier holdings in Sosna v. Iowa ${ }^{61}$ and Vlandis v. Kline, ${ }^{62}$ for

${ }^{55}$ The Clause reads: "All persons born or naturalized in the United States, and subject to the jurisdiction thereof, are citizens of the United States and of the State wherein they reside. No State shall make or enforce any law which shall abridge the privileges or immunities of citizens of the United States." U.S. CONST. amend. XIV, § $1, \mathrm{cl} .1$.

${ }^{56} 83$ U.S. (16 Wall.) 36 (1872).

${ }^{57} 526$ U.S. 489 (1999).

${ }^{58}$ See CAL. WELF. \& INST. CODE $§ 1145.03$ (West 1993) (limiting the benefits new residents could receive under California's Aid to Families with Dependent Children program for the first year they lived in the state to the benefits they would have received in the state of their prior residence).

${ }^{59}$ Saenz, 526 U.S. at 492-96.

${ }^{60}$ The Court had recognized a similar constitutional right to travel in past cases but had not found a stable textual home for the doctrine. See id. at 498-504 (discussing doctrinal evolution of the constitutional right to travel).

${ }^{61} 419$ U.S. 393 (1975). In Sosna, the Court upheld an Iowa law imposing a residency duration requirement upon those wishing to obtain a local divorce.

62412 U.S. 441 (1973). Vlandis involved an unsuccessful challenge to the common practice of state universities to charge in-state residents lower tuition rates than out-of- 
example, by emphasizing the right of states to prevent citizens from entering the state only for the purpose of acquiring a "portable" benefit that they could then take elsewhere. ${ }^{63}$ Such alternative rationales would be necessary to justify durational residency requirements, the Court explained, because a desire to deter undesirable citizens from migrating to a state "would be unequivocally impermissible." ${ }^{.64}$

Following Saenz, a state may not structure its legal entitlementsincluding its policies regarding out-of-state marriages-for the purpose of deterring undesirable couples from migrating to its borders. The right that Lawrence affords to gay couples to form a household and share private intimacy is accompanied by a right to move freely around the country in choosing where to establish that household without being subject to dissuasion. A state cannot assert any interest to the contrary in an interjurisdictional marriage dispute.

\section{Interests that States Might Assert in Denying Recognition}

As I indicated at the outset of this Article, I do not intend to argue that states can never have a legitimate interest in applying forum law, rather than the law of the place of celebration, to the marriage of a gay couple. If one starts from the presumption that a state may forbid gay couples from marrying in the first place-which I do, for purposes of this Article-then there will sometimes be legitimate interests that a state might invoke in refusing to give effect to a marriage performed in another state.

Most importantly, states have a legitimate interest in preventing their domiciliaries from entering into evasive out-of-state marriages for the purpose of circumventing a prohibition contained in local law. In earlier marriage disputes, many courts concluded that evasive marriages directly undermine the laws of the domiciliary forum and encourage other states to show disrespect for forum policies, to the detriment of interstate relations. ${ }^{65}$ Not all states share this view. In

staters.

${ }^{63}$ Saenz, 526 U.S. at 504-05.

${ }^{64} I d$. at 506. The Court also noted that state policies that merely have the effect of deterring migration would only implicate the constitutional right to travel if a functional analysis demonstrated that the extent of the incursion was great. Id. at 504-05. It was policies aimed expressly at deterring migration that the Court condemned in categorical terms.

65 See Koppelman, supra note 15, at 2152-53 (discussing evasive marriages). Compare State v. Ross, 76 N.C. 242, 246-47 (1877) (recognizing a bona fide out-of-state interracial marriage as a defense in a criminal prosecution for fornication and adultery, despite a local antimiscegenation law), with State v. Kennedy, 76 N.C. 251, 252-53 
California, for example, the state supreme court found in 1936 that the values of stability and comity called for the recognition of marriages that were valid where celebrated even in cases of clear and deliberate evasion. ${ }^{66}$ But either treatment of evasive marriages falls within the legitimate range of conflicts principles that a state might choose to embrace.

A state might also be able to assert a generalized interest in uniform application of its laws to all domiciliaries-a desire, that is, not to give effect to nonconforming marriages within the jurisdiction, even when they are the result of bona fide relocations by couples validly married in other states-for reasons of administrative convenience or apprehension about public perceptions of fairness and legitimacy. Since gay people form a significant presence within the civil community-about three percent of the population by conservative estimates $^{67}$ - the potential for a starkly apparent difference in treatment between long-term domiciliaries and recent arrivals is very real. When coupled with the protection that the federal Defense of Marriage Act appears to provide to states from being "required" to recognize the marriages of gay couples, ${ }^{68}$ such interests might suffice to support the actions of a court that is determined not to apply the law of the place of celebration to the marriage under any circumstance.

It is my hope, however, that this Article will help to focus courts on the outcome that a good-faith analysis ought to produce in a marriage recognition dispute involving a gay couple, rather than merely

(1877) (refusing, in a companion case, to recognize an out-of-state interracial marriage where the couple clearly and deliberately evaded local marriage restrictions).

${ }^{66}$ See McDonald v. McDonald, 58 P.2d 163, 164 (Cal. 1936) (holding that, even where parties acted "with the avowed purpose of evading our laws relating to mar riages .... [i]n the absence of ... a statute ... expressly and clearly regulating marriages abroad, the lex loci contractus governs as to the validity of the marriage"); see also CAL. FAM. CODE $§ 308$ (West 2004) (embracing a place-of-celebration rule for California). But see id. $\$ 299.2$ (creating a singular exception to this rule for the marriages of gay and lesbian couples).

${ }^{67}$ See William B. Rubenstein, Do Gay Rights Laws Matter?: An Empirical Assessment, 75 S. CAL. L. REV. 65, 83-86 \& nn.56-65 (2001) (collecting different studies estimating the percentage of self-identified gay people in the general population).

${ }^{68}$ The Act provides, in pertinent part:

No State, territory, or possession of the United States, or Indian tribe, shall be required to give effect to any public act, record, or judicial proceeding of any other State, territory, possession, or tribe respecting a relationship between persons of the same sex that is treated as a marriage under the laws of such other State, territory, possession, or tribe, or a right or claim arising from such relationship.

28 U.S.C. $§ 1738 \mathrm{C}(2000)$. 
asking whether the application of forum law to a gay couple's marriage, for any and all purposes, can plausibly be justified. The doctrines surrounding the treatment of out-of-state marriages have a long history that has produced a well-developed body of case law in almost every state. Those doctrines can offer a refined account of the interests at stake in a marriage recognition dispute: both the interests of the state and those of individual litigants. My purpose here is to aid courts in exploring how those refined answers should apply to the marriages of gay couples in light of the constraints that the Supreme Court has imposed upon the permissible range of interests that a state can legitimately assert in such a case.

In some states, for example, the rejection of nonconforming marriages in past disputes may have rested entirely upon expressions of moral disapproval and a desire to exclude the relationship from the jurisdiction. When confronted with a recognition dispute involving the marriage of a gay couple, a court in such a state should acknowledge that those earlier precedents do not offer much guidance for determining what interests are legitimately at stake in the present dispute. In particular, a court should require a litigant in such a case to identify with precision the "public policy" that it seeks to invoke in urging that the court give no effect to a valid marriage, as the California Court of Appeals did in Dalip Singh Bir. ${ }^{69}$ Similarly, if it becomes clear to a court that a state has restructured its laws concerning out-ofstate marriages for the purpose of dissuading gay couples from migrating to the state, that fact should cause the court to look with skepticism upon any neutral-sounding reasons that the state might offer for refusing to give effect to a couple's marriage in a particular case.

Linda Silberman is correct when she observes that, if a state is determined to deny any effect to the marriage of a gay couple, it could likely circumvent such restrictions by limiting itself to a constitutionally acceptable repertoire of interests when it crafts its litigation position (provided that the legislature's statements of policy on the issue would permit such readjustment) ${ }^{70}$ But the observation is less pointed than Silberman believes. There is real value in mandating a process under which a litigant must offer a complete and precise ac-

${ }^{69}$ See In re Dalip Singh Bir's Estate, 188 P.2d 499, 502 (Cal. Dist. Ct. App. 3d Dist. 1948) (finding that "public policy" was not offended when the purpose for which the nonconforming marriage was offered did not offend any restriction on local California behavior).

${ }^{70}$ See Linda Silberman, Same-Sex Marriage: Refining the Conflict of Laws Analysis, 153 U. PA. L. REV. 2195, 2211-12 (2005). 
count of its position and its reasoning, even if it is clear that the litigant can ultimately prevail once it does so. This is particularly the case when the litigant is the state, for such a process forces the state to take broader responsibility for the policies that it embraces. Thus, a state might be unwilling to adopt the position that all nonconforming marriages of migratory couples (same-sex or otherwise) must be denied any effect in order to avoid perceptions of unfairness in the different options available to long-term domiciliaries and recent arrivals, if that is the only litigation position that will permit the state to achieve its desired outcome. Indeed, in those jurisdictions that already offer some measure of state support to gay couples through domestic partnership or other arrangements, the state might be unable to sustain such an argument with any credibility. ${ }^{71}$

It is asking a lot to require courts to engage in such a careful and detailed analysis of a state's legitimate interests, especially in an area that has such a demonstrated capacity to provoke strong emotions. But I am optimistic that courts will rise to this challenge, for the structural preference for reflection and deliberation that is embedded in the adjudicatory process has a capacity to bring out the better instincts of judges. The type of analysis that I suggest here offers a model for a modest, case-by-case application of the Supreme Court's recent constitutional rulings. Such an approach should be attractive to any state court that wishes to give those constitutional rulings their due but is wary of issuing an unsustainably broad and categorical holding on the question of recognition.

\section{Legislative Prohibitions AND the Mini DefEnSE OF MARRIAGE ACTS}

Since the Hawai'i Supreme Court's decision in Baehr v. Lewin ${ }^{72}$ first drew national attention to the marriage rights of gay and lesbian couples, an increasing number of states have enacted provisions declaring marriages between same-sex couples to be contrary to their public policy and "void." The most recent election cycle saw twelve such provisions enacted in the form of state constitutional amendments, bringing the total count on statutory and constitutional provi-

\footnotetext{
${ }^{71}$ See, e.g., Langan v. St. Vincent's Hosp., 765 N.Y.S.2d 411, 422 (Sup. Ct. Nassau County 2003) (permitting a partner joined in a Vermont civil union to sue as a "spouse" under New York's wrongful death statute in part because of New York City's extension of domestic partner benefits to gay couples).

${ }^{72} 852$ P.2d 44 (Haw. 1993).
} 
sions to thirty-nine. ${ }^{73}$ State courts might be tempted to read these "mini Defense of Marriage Acts" as requiring them to give no effect of any kind to the out-of-state marriages of same-sex couples and to declare them a nullity in all cases, rendering unnecessary any analysis of choice of law, state interests, or individual hardship. But the proper treatment of these provisions is a much more complicated question. State courts have had many occasions in the past to interpret statutory provisions declaring interracial, consanguineous, and other disfavored marriages to be "void," "void ab initio," or "absolutely void." Despite the manifest hostility that such provisions have exhibited toward the targeted relationships, a significant number of courts have adopted mitigating constructions of them. Specifically, these courts have adopted clear-statement rules that have interpreted declarations of invalidity or voidness to apply only to locally celebrated marriages unless the legislature has made explicit its desire to extend those declarations to valid marriages from other jurisdictions.

This clear-statement requirement finds its most forceful expression in cases that involve a request to nullify an existing marriage, as in an annulment proceeding. ${ }^{74}$ This is unsurprising, since a rule

${ }^{73}$ See Koppelman, supra note 15, app.

${ }^{74}$ See, e.g., McDonald v. McDonald, 58 P.2d 163, 164 (Cal. 1936) (denying a request for annulment because, "[i]n the absence of ... a statute... expressly and clearly regulating marriages abroad, the lex loci contractus governs as to the validity of the marriage"); Hilliard v. Hilliard, 209 N.Y.S.2d 132, 134 (Sup. Ct. Greene County 1960) (denying a request for annulment and refusing to apply state law declaring underage marriages to be "void" to an out-of-state marriage in the absence of clear legislative intent); Campione v. Campione, 107 N.Y.S.2d 170, 171 (Sup. Ct. Queens County 1951) (same for an uncle/niece marriage); Garcia v. Garcia, 127 N.W. 586, 588-90 (S.D. 1910) (adopting a clear-statement requirement in denying the request for a unilateral annulment of a first-cousin marriage).

The Supreme Court of Oklahoma adopted a similar rule in the case of an interracial marriage that was validly celebrated within an Indian territory that later came under the jurisdiction of an Oklahoma law declaring such marriages null and void. The court concluded that it should only apply the antimiscegenation law prospectively and not interpret it to void prior marriages, despite the strong public policy of the state on the issue, because of the hardship that would otherwise result:

The wisdom of [antimiscegenation] acts prohibiting future marriage between such persons has also received the approbation of some of the most respectable courts of the land. It is said that the amalgamation of the white and black races is productive of deplorable results, but an act designed to wipe out by the wholesale legal, existing marriages between members of the white and black races would be almost profligate in its tendency, and productive of even more deplorable results. We would be unwilling to say that the Legislature intended to destroy legal relations, such as that of marriage which had already become fixed, in the absence of plain and unmistakable language to that effect in the act. 
authorizing a spouse to obtain a unilateral order of annulment could permanently extinguish the legitimate expectations of the other spouse whenever the couple, or perhaps even one spouse, traveled through a hostile state. As the Supreme Judicial Court of Massachusetts said in Medway $v$. Needham, one of the most widely discussed of the early marriage cases, "it would produce greater inconveniences than those attempted to be guarded against, if a contract of this solemn nature, valid in a neighboring state, could be dissolved at the will of either of the parties, by stepping over the line of a state, which might prohibit such marriages." ${ }^{75}$ Even where the local feeling toward a disfavored marriage is strident, courts have been unwilling to impose such harsh results without unmistakable legislative direction. ${ }^{76}$ Indeed, if a state with no significant contacts with an out-of-state marriage sought to nullify the marriage on the basis of a transient exercise of jurisdiction, and thereby to transform the personal and property rights of the spouses according to its own forum law upon their return to the marital domicile, that act would seem to violate the constitutional limits on legislative jurisdiction set forth in Allstate v. Hague and Phillips Petroleum v. Shutts. ${ }^{77}$ Courts thus have good reason to tread cautiously in cases involving annulment.

A significant number of courts have also adopted clear-statement rules in custody disputes and in probate proceedings and other suits

Scott v. Epperson, 284 P. 19, 21 (Okla. 1930).

7516 Mass. (15 Tyng) 157, 159 (1819); see also, e.g., Garcia, 127 N.W. at 588-89 (discussing and adopting Medway's clear-statement reasoning).

${ }^{76}$ Naturally, there are exceptions. In one prominent case, for example, the Supreme Court of Virginia affirmed an order nullifying an evasive interracial marriage without any such clear legislative direction. See Naim v. Naim, 87 S.E.2d 749 (Va. 1955). The bulk of the court's reasoning in that case was devoted to rejecting a constitutional challenge to the restrictive Virginia marriage law; it did not address the interjurisdictional feature of the dispute at all. See id. at 750-56.

While the Ohio Supreme Court did not address the issue in either case, the particular hardship associated with a unilateral annulment may account in part for the different results that the court reached on the recognition of uncle/niece marriages in Mazzolini v. Mazzolini, 155 N.E.2d 206 (Ohio 1958), in which it refused to annul an evasive marriage entered into by an uncle and his niece, and its later repudiation of that case in In re Estate of Stiles, 391 N.E.2d 1026, 1027 (Ohio 1979), in which it gave no effect to an uncle/niece marriage in an intestacy proceeding.

${ }^{77}$ In Allstate, the Court found that the Due Process and Full Faith and Credit Clauses together require that a state have a significant aggregation of contacts with a transaction or dispute before applying its laws to that dispute. Allstate Ins. Co. v. Hague, 449 U.S. 302, 308 (1981). In Shutts, the Court found this requirement to be violated in cases where the only contact between the forum and the dispute consisted in the decision of the plaintiff to file suit in the forum. Phillips Petroleum Co.v. Shutts, 472 U.S. 797, 815-23 (1985). 
involving property rights, even though the prospective treatment of the marriage itself has not been at stake. Invoking the language of extraterritoriality, these courts have insisted that the legislature make clear its intent to interfere with rights and expectations created by the law of another forum before it will apply its declaration of voidness to a valid marriage performed abroad. In a 1986 custody dispute, for example, the Supreme Court of Arkansas interpreted a state statute that declared first-cousin marriages "absolutely void" to apply only to marriages performed locally, despite the unqualified language, because the statute did not expressly provide that "marriages such as the one involved here, celebrated in another state, are void in the State of Arkansas." ${ }^{, 7}$ Even though the marriage in question was deliberately evasive-the father had attempted to marry his cousin in Arkansas, discovered that the marriage was prohibited, and then "made a trip to Texas for the sole purpose of remarrying there" insisted upon receiving express legislative direction before it would extend its local prohibition to an out-of-state marriage. ${ }^{80}$

Among the thirty-nine states that have enacted explicit bans on marriage between gay couples, there is considerable variation in the clarity and scope of the legislative prohibition. Many of these states have expressly considered the possibility of valid out-of-state marriages and have enacted unmistakable prohibitions against giving them any local effect. ${ }^{81}$ But in twelve of the thirty-nine states-Hawai'i, Illinois,

${ }^{78}$ Etheridge v. Shaddock, 706 S.W.2d 395, 396 (Ark. 1986) (citation omitted); see also State v. Graves, 307 S.W.2d 545, 547-48 (Ark. 1957) (embracing the clear-statement rule in a criminal prosecution arising from evasive underage marriage); In re Miller's Estate, 214 N.W. 428, 429 (Mich. 1927) (embracing a presumption in favor of recognizing valid marriages unless the legislature has made clear that certain types of out-ofstate marriages should not be valid); In re May's Estate, 114 N.E.2d 4, 7 (N.Y. 1953) (invoking the rule where the statute declaring uncle/niece marriages "void" "does not expressly ... void a marriage ... solemnized in a foreign State where such marriage is valid, the statute's scope should not be extended by judicial construction"); Van Voorhis v. Brintnall, 86 N.Y. 18, 32-34 (1881) (same).

${ }^{79}$ Etheridge, 706 S.W.2d at 396.

${ }^{80}$ The opinion does not explain the precise role that the out-of-state marriage played in the custody dispute. The mother identified the father's remarriage in Texas as a change of conditions sufficient to warrant a modification of the custody order. See $i d$. at 395-96. Her argument appears to have been that the father's maintenance of a marriage in Arkansas in violation of Arkansas law constituted a basis for questioning his fitness as a parent and hence revisiting custody. In giving effect to the Texas marriage, the chancellor effectively held that a parent did nothing "wrong" for custody purposes, when he engaged in evasive behavior in order to enter into a marriage that local law would have prohibited.

${ }^{81}$ See, e.g., FLA. STAT. ANN. \$ 741.212 (West Supp. 2005) (declaring that "marriages between persons of the same sex entered into in any jurisdiction, whether within 
Iowa, Maryland, Montana, New Hampshire, South Carolina, South Dakota, Texas, Vermont, Washington, and Wyoming - the legislature has made no mention of extraterritoriality or the treatment of marriages that have been validly celebrated in other jurisdictions. ${ }^{82}$ As interjurisdictional marriage disputes involving gay couples begin to arise, courts in those states will have to look carefully at the purposes for which those couples request that their marriages be given effect, particularly where a denial of their request would frustrate reasonable expectations or produce significant hardship. Since states may not exclude gay relationships from their territory, may not attempt to dissuade those couples from migrating to the state, and may not subject them to disfavored treatment solely on the basis of moral disapproval-such that the range of interests that a state can offer in applying forum law to a bona fide out-of-state marriage is significantly constrained-there is good reason to demand clarity from a legislature before assuming that it intended to impose such harsh results.

or outside the State of Florida ... are not recognized for any purpose in this state"); MO. ANN. STAT. § 451.022(4) (West 2003) ("A marriage between persons of the same sex will not be recognized for any purpose in this state even when valid where contracted.").

Some of these provisions are remarkably punitive. In Arkansas, for example, the legislature has provided:

Any marriage entered into by persons of the same sex, where a marriage license is issued by another state or by a foreign jurisdiction, shall be void in Arkansas and any contractual or other rights granted by virtue of that license, including its termination, shall be unenforceable in the Arkansas courts.

ARK. CODE ANN. § 9-11-208(c) (Michie 2002). The last portion of the statute would appear to require Arkansas courts to disregard judgments involving custody, support and other aspects of a marital dissolution. Alaska has a similar provision. See ALASKA STAT. \$ 25.05.013 (Michie 2004) ("A marriage entered into by persons of the same sex, either under common law or under statute, that is recognized by another state or foreign jurisdiction is void in this state, and contractual rights granted by virtue of the marriage, including its termination, are unenforceable in this state.").

${ }^{82}$ The provisions in these states restrict the civil institution of marriage to opposite-sex couples, often rejecting as "void" any marriage performed between a same-sex couple, but they make no mention of the treatment of marriages celebrated elsewhere. See Haw. Rev. Stat. §572-1 (Supp. 2003); 750 Ill. Comp. Stat. AnN. §§ 5/212 \& 5/213.1 (West 1999); Iowa Code AnN. $\$ 595.2$ (West 2000); Md. Code ANn., Fam. LAW § 2-201 (1999); Mont. Code ANN. § 40-1-401 (2003); N.H. Rev. STAT. ANN. §§ 457:1-2 (Supp. 2004); S.C. CoDE ANN. \$§ 20-1-10 \& 15 (Law. Co-op. Supp. 2004); S.D. CODIFIED LAWS § 25-1-1 (Michie 2004), TEX. FAM. CodE ANN. § 2.001 (Vernon 1998); Vt. Stat. AnN. tit. 15, §8 (2002); Wash. Rev. Code AnN. \$ 26.04.010 (West Supp. 2005); WYo. STAT. ANN. § 20-1-101 (Michie 2003). 


\section{A BROADER CONTEXT FOR THE RECOGNITION QUESTION}

There is another important reason to train our focus upon the fact that, following Lawrence, Romer, and Saenz, states may not attempt to exclude gay relationships from their territory when they structure their domestic laws. The observation speaks to a broader fact about the manner in which discrimination against gay men and lesbians is often accomplished-that is, the distinctive mode of subordination often embodied in laws that are hostile toward gay people. Antigay policies regularly proceed on the assumption that, if the state simply refuses to acknowledge the existence of gay people and their relationships, those people and their relationships will actually cease to be. Because gay identity is not readily apparent, and because the mechanism of the closet can operate with astonishing tenacity and power to erase gay identity when it is not consistently and actively expressed, those who wish to exclude gay people from civil society can often accomplish that task simply by behaving as though gay people and their relationships did not exist. ${ }^{83}$ I have referred to this dynamic as the denial of the homosexual possibility. ${ }^{84}$ The most conspicuous instance of this mode of subordination in American law is the U.S. military's Don't Ask, Don't Tell policy, which explicitly requires gay soldiers to maintain a state of complete social invisibility if they wish to serve, in order to foster in straight soldiers the comforting illusion that the military is a gay-free zone. But Don't Ask, Don't Tell is remarkable only for the overtness of the coerced invisibility that it employs, not the fact of it.

This dynamic is very much in evidence in discussions about the relationship rights of gay couples. In both constitutional disputes and policy debates over marriage or civil unions, those who are hostile toward gay couples regularly frame their arguments around the implicit assumption that gay couples can be removed from civil society altogether. The maneuver is clearly in evidence, for example, in discussions about children.

\footnotetext{
${ }^{83}$ Professor Kenji Yoshino's discussion of this distinctive mode of subordination is the most theoretically rich. See generally Kenji Yoshino, Covering, 111 YALE L.J. 769 (2002) (discussing a range of behaviors that gay people offer in response to pressure to remain in the closet and the ways in which the law fosters or encourages those "covering" behaviors); Kenji Yoshino, Assimilationist Bias in Equal Protection: The Visibility Presumption and the Case of "Don't Ask, Don't Tell," 108 YALE L.J. 485 (1998) (arguing, contrary to received understanding of equal protection, that invisibility or ability to assimilate can contribute to political powerlessness).

${ }^{84}$ See Tobias Barrington Wolff, Political Representation and Accountability Under Don't Ask, Don't Tell, 89 Iowa L. ReV. 1633, 1635 (2004).
} 
Antigay arguments often make broad assertions about the superiority of opposite-sex couples as parents and caregivers for children. As it happens, these assertions are belied by all the responsible social science data on the question, which consistently show that gay parents are no more likely to have bad outcomes with their children than are straight parents. ${ }^{85}$ More importantly, however, these assertions exhibit a seeming illogic as a basis for arguing that gay couples should be prohibited from marrying. Gay parents exist in large numbers and will continue to exist without regard to the access that gay couples enjoy to the protections of civil marriage. ${ }^{86}$ Lesbians enjoy the same fundamental right that every woman has to become pregnant and raise children. Gay men and lesbians continue to have children in opposite-sex relationships before coming out of the closet. And gay people serve as adoptive or foster parents, in one form or another, throughout the United States. The question is not whether gay parents exist, or whether they should exist-they do, and they will. The question is what policies the state should adopt in making protections and support available to those parents. Even if there were any truth to the assertion that gay couples are less good on average at being parents, denying them the support and protection associated with civil marriage would not prevent them from being parents. It would simply undermine further their ability to provide a stable and nurturing home. To offer a simple point of contrast: it would be absurd to suggest that poor couples should not be allowed to marry, merely because their children are more likely to have bad outcomes as a result of their poverty. The rational response to the problems experienced by poor families is to make more support available to them, not less. How, then, does it make sense to argue that it is in the best interest of children to deny any support or recognition to the relationships of their gay and lesbian parents?

The answer is that these arguments about children are logically coherent only if one implicitly frames the debate as a referendum on whether there should be gay parents at all. If one starts from the presumption that gay parents can be made to go away through the expe-

\footnotetext{
${ }^{85}$ See generally Judith Stacey \& Timothy J. Biblarz, (How) Does the Sexual Orientation of Parents Matter?, 66 AM. SOC. REv. 159 (2001) (conducting a comprehensive review of sociological studies of gay and lesbian parents and concluding that those studies accurately report no difference in adverse outcomes based upon sexual orientation).

${ }^{86}$ See Gary J. Gates \& JAson Ost, The Gay \& Lesbian AtLas 44-47 (2004) (collecting and analyzing data from the 2000 U.S. Census regarding children being raised by same-sex partners).
} 
dient of passing laws, then a policy of refusing all forms of legal assistance and recognition to gay parents might seem to be a logical position for one who believes that gay people should not be parents. Of course, if confronted directly with a question about whether the passage of laws can actually make gay parents cease to exist, opponents of gay couples will be unlikely to claim such magical powers for the law. The point of the argument is not to describe an actual state of affairs that might be brought about through legislation. The point of the argument, rather, is to encourage people to think and act as if such legislative transformation were possible. That is what is meant by the term "mode of subordination." It is a behaving-as-if-a way of thinking and acting that will keep a group in a disempowered position, even when the factual predicates on which that way of thinking and acting rests are demonstrably false. ${ }^{87}$ When opponents of gay couples frame the debate over marriage as a discussion about the best interests of children, they contribute to the erasure of gay couples and their children as a distinct social presence. ${ }^{88}$ At the same time, they render invisible the very real harms that the children of gay couples suffer from the denial of equal support and assistance to their parents. ${ }^{89}$

There is a powerful potential for this same dynamic to intrude upon every dispute over the effect that the marriage of a gay couple

${ }^{87}$ I see strong parallels here with Janet Halley's brilliant reading of acts and identity in Bowers v. Hardwick. See Janet E. Halley, Reasoning About Sodomy: Act and Identity in and After Bowers v. Hardwick, 79 VA. L. REV. 1721 (1993). Halley identifies a "chiastic" gesture that runs throughout the majority opinion in Bowers in which the Court moves seemlessly between two arguments: the assertion that gayness is defined by the commission of a shameful act (sodomy) and the assertion that gayness constitutes a personal identity. See id. at 1745-49. In Halley's reading, this "double bind" creates a constantly shifting terrain in which opponents of gay litigants can always select the argument ("gay" as act; "gay" as identity) that best enables them to defeat a claim of right. "The master of a double bind," as Halley puts it, "always has somewhere to go." Id. at 1749. In my reading of the arguments surrounding marriage, opponents of gay couples add an ironic element to this chiasmus. The submerged argument-the fantasy that gay people can be made to disappear through the act of legislation-usually remains unspoken, rather than being invoked explicitly, as with the act/identity binary. Nonetheless, that argument remains fully perceptible to the key audiencethose who ardently desire to believe that gay people can in fact be legislated out of existence-and it operates to smooth over the cognitive dissonance that would otherwise flow from the unreal and illogical foundations of the arguments upon which opponents of gay couples explicitly rely.

${ }^{88}$ See Eskridge, supra note 52, at 1365-72 (explaining that the primary effect of antigay public policy is to make it more difficult or dangerous for gay people to have a visible social presence in the community).

${ }^{89}$ See id. at 1374-75 \& nn.199-205 (detailing harms suffered by gay people and their families as a result of compelled social invisibility). 
should be given across state lines. In debating how to treat a gay couple that marries in one jurisdiction and relocates to another, opponents of recognition often implicitly frame their arguments as a question about whether those couples ought to be present in the state at all as a visible social presence. If pressed, of course, most of these opponents will acknowledge that gay people will continue to exist regardless of how laws are structured. They may even grudgingly admit that states have no power to exclude out-of-state gay couples from migrating to their territory. But when these facts are allowed to go unstated, the opponents will revert to arguments that operate from the premise that gay couples and gay parents will cease to exist within their jurisdiction if the law excludes them from its ambit. In doing so, they also shield themselves from the knowledge of the hardship that gay couples and their children will experience if the state refuses to give effect to their relationship rights. This behaving-as-if makes it easier to maintain a hostile posture toward the recognition of a gay couple's marriage while still preserving a self-image of fairness and reasonableness.

Indeed, in several important respects, the recognition question for marriages between same-sex couples has an entirely different character from every major dispute over marriage policy that has preceded it. These differences have analytical implications that will require the careful attention of state court judges.

First, one of the basic purposes of a restriction on prohibited conduct is to channel the regulated population into more acceptable forms of behavior. In the case of restrictions on marriage, the prohibition on disfavored relationships has always carried with it an implied mandate that people seek their life partners from a population that the state deems acceptable. In past disputes over disfavored relationships, that mandate has always left citizens with meaningful opportunities to find a spouse and marry. There has never been any serious suggestion, for example, that significant numbers of people experience themselves as "interracially oriented" or "incestuously oriented." As painful and disruptive as it is for any person to be told that she cannot marry a particular person with whom she has fallen in love, the fact remains that even those marriage restrictions that we now deem offensive, like the antimiscegenation laws, left people with a real ability to pursue other options and build a life together with a spouse. The same is not true of prohibitions on marriage by gay couples. Most people-gay and straight-do experience themselves as having only one option when it comes to the gender of their partners. That 
is why we specify an identity category of "sexual orientation." In the past, analyses of the equities and hardships attending a marriage restriction have relied upon the assumption that the individuals involved had other options available to them in selecting a spouse. That assumption is not an appropriate one in the present context.

Second, and relatedly, in disputes involving race, consanguinity, age, and divorce following adultery, unlike in the present context, it has always been clearly established at the time the dispute arose that the jurisdiction in fact had the power to criminalize or exclude the disputed relationship entirely from its borders. Thus, there is already an existing jurisprudential tendency in the doctrine to frame the recognition question as a debate about whether the relationship should be permitted within the jurisdiction at all. The particular mode of subordination that gay people must contend with-their compelled erasure or invisibility-threatens to offer powerful, synergistic reinforcement to this preexisting tendency in the doctrine of cross-border marriage disputes. A responsible court must recognize this fact and avoid this analytical mistake.

The proper question in a recognition case is not: should gay couples be allowed within the jurisdiction at all? The proper question is: given that gay couples from other states may relocate and move freely within the jurisdiction, does it make sense to give no effect to their validly celebrated marriages, with all the attendant disruption to property interests, custodial arrangements, and long-term planning that such a refusal will entail? Or does it make more sense to give effect to those relationships in ways that preserve reasonable expectations and avoid hardship, even when doing so diverges from the choices that the local jurisdiction has made about the options available to its own domiciliaries? When framed in these terms, the policy analysis surrounding the recognition question looks very different.

\section{CONCLUSION}

When a court must rely upon broad and categorical constitutional arguments in order to resolve a dispute, it is an indication that there has been an institutional failure of sorts-a failure by the legislature to conform its policies to the larger set of norms that constrain its authority, or a failure of the court's own process of incremental decision making to provide a workable solution for a new problem. While a court should not hesitate to enforce broad constitutional principles in appropriate cases, neither should it assume that the Constitution can only operate in sweeping gestures. Past disputes over race, con- 
sanguinity, age, and other contested relationship categories have produced a set of common-law doctrines that equip courts to ask careful questions about the proper treatment of nonconforming marriages in interjurisdictional disputes. The Supreme Court's constitutional rulings in Lawrence, Romer, and Saenz can fit comfortably within those doctrines, pruning and trimming the range of interests that a state may legitimately assert in a cross-border marriage case without uprooting the established forms altogether. Until the nation achieves a broader constitutional consensus on the marriage rights of gay and lesbian couples, courts will have to exhibit care and diligence in performing this important task. 